\title{
Determination of the Leaflet Area of Schinus terebinthifolius Raddi in Function of Linear Dimensions
}

\author{
Vinicius de Souza Oliveira ${ }^{1}$, André Monzoli Covre ${ }^{1}$, Drielly Stephania Gouvea ${ }^{1}$, Luciano Canal $^{1}$, \\ Karina Tiemi Hassuda dos Santos ${ }^{2}$, Jéssica Sayuri Hassuda Santos ${ }^{2}$, Gleyce Pereira Santos ${ }^{2}$, \\ Ana Paula Braido Pinheiro ${ }^{1}$, Omar Schmildt ${ }^{1}$, Robson Prucoli Posse ${ }^{3}$, Marcio Paulo Czepak ${ }^{2}$, \\ Sara Dousseau Arantes ${ }^{4}$, Rodrigo Sobreira Alexandre ${ }^{5}$, José Augusto Teixeira do Amaral ${ }^{5}$, \\ Edney Leandro da Vitória ${ }^{2} \&$ Edilson Romais Schmildt ${ }^{2}$ \\ ${ }^{1}$ Postgraduate Program in Tropical Agriculture, Federal University of Espírito Santo, São Mateus, ES, Brazil \\ ${ }^{2}$ Departament of Agrarian and Biological Sciences, Federal University of Espírito Santo, São Mateus, ES, Brazil \\ ${ }^{3}$ Federal Institute of Espírito Santo, Campus Itapina, Colatina, Espírito Santo, Brazil \\ ${ }^{4}$ Capixaba Institute for Research, Technical Assistance and Rural Extension, Regional Center for Rural \\ Development, Brazil \\ ${ }^{5}$ Federal University of Espírito Santo, Alegre, ES, Brazil \\ Correspondence: Vinicius de Souza Oliveira, Postgraduate Program in Tropical Agriculture, Federal University \\ of Espírito Santo, São Mateus, ES, Brazil. E-mail: souzaoliveiravini@gmail.com
}

Received: May 12, 2019 Accepted: June 24, $2019 \quad$ Online Published: August 31, 2019

doi:10.5539/jas.v11n14p198 URL: https://doi.org/10.5539/jas.v11n14p198

\begin{abstract}
The objective of this study was to select mathematical equations that best fit the estimation of the leaf area of pink pepper (Schinus terebinthifolius Raddi) from the linear leaflet dimensions. 500 leaflets with different physiological ages of a commercial plantation were collected, located in the region of Gameleira, municipality of São Mateus, North of the State of Espírito Santo, Brazil. Was measured the length (L) along the main midrib, the largest width (W) and the observed leaf area (OLA) of each sheet. The product of the multiplication between L and $\mathrm{W}$ of the leaflets (LW) was determined. For the modeling the measurements of 400 leaflets were used, where OLA was used in function of $\mathrm{L}, \mathrm{W}$ or $\mathrm{LW}$. Based on the models found, we obtained the estimated leaf area (ELA). A simple linear regression was fitted for each proposed model of OLA in function of ELA. We tested the hypotheses $\mathrm{H}_{0}: \beta_{0}=0$ versus Ha: $\beta_{0} \neq 0$ and $\mathrm{H}_{0}: \beta_{1}=1$ versus Ha: $\beta_{1} \neq 1$, using Student's $t$ test at $5 \%$ probability. The mean values of ELA and OLA were compared by Student's $t$ test $5 \%$ probability. It was determined the mean error (E), mean absolute error (MAE), root mean square error (RMSE) and Willmott $d$ index. The best adjusted equation was chosen by linear coefficient $\left(\beta_{0}\right)$ not different from zero, angular coefficient $\left(\beta_{1}\right)$ not unlike one, non-significant values of ELA and OLA, E, EAM and RQME closer to zero and Willmott's index d closer to one. In this way, the leaf area of leaflets of Schinus terebinthifolius Raddi can be estimated by the quadratic model equation ELA $=-2.6646+2.2124(\mathrm{~W})+1.3953(\mathrm{~W})^{2}$, using only the width of the leaves as a measure.
\end{abstract}

Keywords: Schinus terebinthifolius Raddi, mathematical equations, non-destructive method, modeling of the leaf area, leaf area estimation

\section{Introduction}

The pink pepper (Schinus terebinthifolius Raddi) is a species belonging to the family Anacardiaceae, also known as red aroeira, aroeira mansa, aroeira pimenteira, aroeira of the beach (Paiva \& Aloufa, 2009). Native to South America (Degáspari, Waszczynskyj, \& Prado, 2005), is widely distributed throughout the Brazilian territory, especially in regions of the Atlantic Forest (Santana, Sartorelli, Lago, \& Matsuo, 2012).

It is a medium sized plant with composite and aromatic leaves (Ceruks, Romoff, Fávero, \& Lago, 2007) and small flowers, grouped in inflorescences (Silva, Nogueira, Oliveira, \& Santos, 2008). The fruits are of the drupe type, when ripe, they present a red and lustrous coloration, whose smell resembles that of the pepper (Oliveira Junior et al., 2013). The red bark resembles a paper, which involves the seed (Degáspari et al., 2005). The seed is unique, presenting dark brown coloration with a diameter of 4 to $5 \mathrm{~mm}$ (Degáspari et al., 2005; Lorenzi \& Matos, 
2008).

According to Paiva and Aloufa (2009), this species has increased pharmacological use, being considered by popular medicine as astringent, anti-diarrheal, anti-inflammatory, depurative, diuretic and febrifuge. Studies with $S$. terebinthifolius have shown great antifungal potential, through the extraction of essential oils present in the leaves in the plant (Braga et al., 2007; Oliveira Junior et al., 2013).

The determination of leaf area is one of the most important measures related to plant growth (S. Bianco, M. S. Bianco, \& Carvalho, 2008), being associated to factors such as light interception, photosynthetic efficiency, evapotranspiration and behavior related to irrigation and fertilizer responses (Blanco \& Folegatti, 2005).

There are several methods to determine the leaf area of a plant, of which they are classified as direct or indirect. The direct methods, although accurate, are mostly destructive, which prevents constant measurements in the same plant, another disadvantage is that they require complex and expensive equipment (Pompelli et al., 2012). Indirect methods, however, do not destroy the leaves, allowing successive evaluations of the same plant during its cycle, as well as expediting the evaluations (Toebe, Cargnelutti Filho, Loose, Heldwein, \& Zanon, 2012).

Among the indirect methods, the getting of mathematical equation models based on linear leaf dimensions has been reported in several studies (Peksen, 2007; Rouphael, Colla, Fanasca, \& Karam, 2007; Antunes, Pompelli, Carretero, \& Damatta, 2008; Toebe, Brum, Lopes, Cargnelutti Filho, \& Silveira, 2010; ompelli et al., 2012; Toebe et al., 2012, Buttaro, Rouphael, Rivera, Colla, \& Gonnella, 2015; Santos et al., 2016; Schmildt, Oliari, Schmildt, Alexandre, \& Pires, 2016; Vitória et al., 2018; Ribeiro et al., 2019; Oliveira et al., 2019), demonstrating that this technique is an important tool for evaluating the leaf area of several species.

Regarding pink pepper, a non-destructive methodology for the determination of its leaf area is of great importance, since there are no mathematical equations in the literature that allow this measurement in the species. For this reason, this work aimed to select the equations that best fit the determination of the leaf area of pink pepper plants (Schinus terebinthifolius Raddi) from the linear dimensions of the leaflets.

\section{Method}

The study was carried out in commercial plantations of pink pepper (Schinus terebinthifolius Raddi), located in the region of Gameleira, municipality of São Mateus, North of Espírito Santo State, Brazil (South latitude $18^{\circ} 40^{\prime} 36^{\prime \prime}$ and $39^{\circ} 51^{\prime} 35^{\prime \prime}$ east longitude). The climate of the region is tropical with dry winter and rainy summer, Aw type according to Köppen classification (Alvares, Stape, Sentelhas, Gonçalves, \& Sparovek, 2014).

The leaves containing the leaflets were collected in vegetatively propagated pink pepper plants, popularly known in the region by the name of "Peludinha", due to the presence of hairiness at the ends of the branches and shoots. Were used productive plants, cultivated in full sun, under the spacing of $5 \times 5$ meters.

Two intact, uninjured or deformed leaves were collected in the middle third of the plant, containing on average seven leaflets per leaf, in approximately 40 plants. Care was taken to highlight the leaves at their insertion, so that only the photosynthetically active portion of the leaf was sampled. In total, 496 leaflets with different physiological ages were collected.

After the collection, the leaves were taken to the Laboratory of Plant Improvement at the University of Espírito Santo, Federal University of Espírito Santo, where the analyzes of the area of the leaflets were carried out. First, the length $(\mathrm{L}$, in $\mathrm{cm})$ was measured on the main midrib, considering the point of insertion of the limbus in the petiole to the apex, and the largest width $(\mathrm{W}$, in $\mathrm{cm}$ ) in the medial position of the limbus perpendicularly to the main midrib, with the aid of a graduated ruler (Figure 1). Then the product of the multiplication between the L and $\mathrm{W}$ of leaflets was determined $\left(\mathrm{LW}\right.$, in $\left.\mathrm{cm}^{2}\right)$. 
$\mathrm{L}$

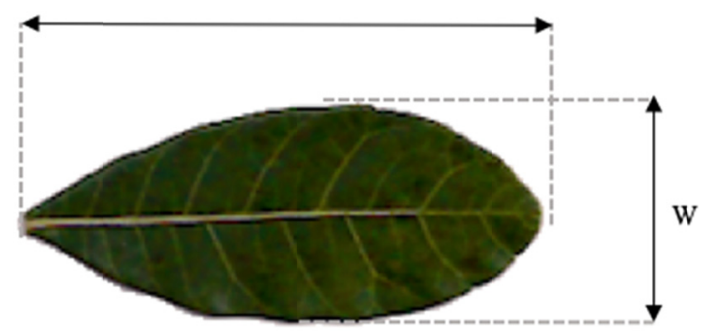

Figure 1. Representation of the length (L) along the midrib and the maximum width (W) of leaflets of Schinus terebinthifolius Raddi

All leaflets were then digitized in their natural color with the aid of an HP Deskjet F4280 ${ }^{\circledR}$ scanner, set at 75 dpi resolution and TIFF format (Tag Image File Format). Then the images were processed by Image $J^{\circledR}$ public domain software (Schindelin, Rueden, Hiner, \& Eliceiri, 2015) to obtain the observed leaf area (OLA, in $\left.\mathrm{cm}^{2}\right)$ of each leaflet. Among the 496 sampled leaflets, 400 leaflets were randomly selected to obtain the modeling equations, and 96 leaflets were used to validate them. Measures of central tendency and variability were calculated.

To model the OLA (dependent variable) in function of $\mathrm{L}, \mathrm{W}$ or LW of the 400 leaflets as independent variables, the following models were used: first degree linear $\left(\operatorname{ELA}=\widehat{\beta}_{0}+\widehat{\beta}_{1} x\right)$, quadratic $\left(\mathrm{ELA}=\widehat{\beta}_{0}+\widehat{\beta}_{1} \mathrm{x}+\widehat{\beta}_{2} \mathrm{x}^{2}\right)$ and power $\left(E L A=\widehat{\beta}_{0} x^{\hat{\beta}_{1}}\right)$, and their respective coefficient of determination $\left(R^{2}\right)$. The parameters $\beta_{0}$ and $\beta_{1}$ were estimated using the least squares method.

For the validation the values of $\mathrm{L}, \mathrm{W}$ and $\mathrm{LW}$ of 96 leaflets were substituted in the modeling equations thus obtaining the estimated leaf area (ELA, in $\mathrm{cm}^{2}$ ). In each model, initially a simple linear regression was fitted $\left(E L A=\hat{\beta}_{0}+\widehat{\beta}_{1} x\right)$ of OLA as a dependent variable in function of ELA as an independent variable.

We tested the hypotheses $\mathrm{H}_{0}: \beta_{0}=0$ versus $\mathrm{Ha}: \beta_{0} \neq 0$ and $\mathrm{H}_{0}: \beta_{1}=1$ versus Ha: $\beta_{1} \neq 1$, using Student's $t$ test at $5 \%$ probability. The means obtained from ELA and OLA were compared by Student's $t$ test at $5 \%$ of probability. It was also determined the mean error (E), the mean absolute error (MAE), the root mean square error (RMSE) and the Willmott d index (Willmott, 1981), for all equations, by means of Equations 1, 2, 3 and 4.

$$
\begin{gathered}
\mathrm{E}=\frac{\sum_{\mathrm{i}=1}^{\mathrm{n}}(\mathrm{ELA}-\mathrm{OLA})}{\mathrm{n}} \\
\mathrm{EAM}=\frac{\sum_{\mathrm{i}=1}^{\mathrm{n}}|\mathrm{ELA}-\mathrm{OLA}|}{\mathrm{n}} \\
\mathrm{RQME}=\sqrt{\frac{\sum_{\mathrm{i}=1}^{\mathrm{n}}(\mathrm{ELA}-\mathrm{OLA})^{2}}{\mathrm{n}}} \\
\mathrm{d}=1-\left[\frac{\sum_{\mathrm{i}=1}^{\mathrm{n}}\left(\mathrm{ELA}_{\mathrm{i}}-\mathrm{OLA}_{\mathrm{i}}\right)^{2}}{\sum_{\mathrm{i}=1}^{\mathrm{n}}\left(\left|\mathrm{ELA}_{\mathrm{i}}-\overline{\mathrm{OLA}}\right|+\left|\mathrm{OLA}_{\mathrm{i}}-\overline{\mathrm{OLA}}\right|\right)^{2}}\right]
\end{gathered}
$$

Where, ELA are the estimated values of leaf area; OLA are the observed values of leaf area; $\overline{\text { OLA }}$ is the mean of the observed values; $n$ is the number of leaflets $(n=96)$.

The criteria used to select the equations that best estimate leaflet area as a function of $\mathrm{L}, \mathrm{W}$ or $\mathrm{LW}$ were: linear coefficient $\left(\beta_{0}\right)$ not non-zero, angular coefficient $\left(\beta_{1}\right)$ not unlike one, non-significant values in the comparison of the means of ELA and OLA, E, EAM and RQME closer to zero and Willmott's index d (Willmott, 1981) closer to one. Statistical analyzes were performed with the aid of software R (R Core Team, 2018), by the data package ExpDes.pt version 1.2 (Ferreira, Cavalcanti, \& Nogueira, 2018).

\section{Results and Discussion}

The high amplitude of the leaf dimensions of length (L), width (W), product of the length with the width (LW) and observed leaf area (OLA) of the samples used for the modeling and for the validation, represented by the high values of the coefficient of variation (CV) and standard deviation (SD) can be observed in Table 1. This high variability is desirable in studies to obtain mathematical equations for the estimation of leaf area since it reflects the use of leaves with different proportions, being a representative sample of the population contemplating all stages of development of the plant. In this way, the data set can be considered appropriate for the present study (Alves et al., 2016). 
Table 1. Minimum, max, average, amplitude, standard deviation (SD) and coefficient of variation (CV) values of the variables: length (L); width (W); product of the length and width (LW) and observed leaf area (OLA) of leaflets of Schinus terebinthifolius Raddi

\begin{tabular}{llllllll}
\hline Variable & Unit & Minimum & Max & Average & Amplitude & SD & CV (\%) \\
\hline 400 leaves were used for modeling & & & & & & \\
$\mathrm{L}$ & $\mathrm{cm}$ & 2.90 & 10.50 & 6.15 & 7.60 & 1.48 & 24.14 \\
$\mathrm{~W}$ & $\mathrm{~cm}$ & 1.20 & 4.60 & 2.60 & 3.40 & 0.51 & 19.68 \\
$\mathrm{LW}$ & $\mathrm{cm}^{2}$ & 3.96 & 48.30 & 16.66 & 44.34 & 7.06 & 42.38 \\
OLA & $\mathrm{cm}^{2}$ & 3.29 & 36.04 & 12.91 & 32.75 & 5.26 & 40.76 \\
\hline 96 leaves for validation & & & & & & 26.77 \\
$\mathrm{~L}$ & $\mathrm{~cm}$ & 3.40 & 10.30 & 6.27 & 6.90 & 1.68 & 23.19 \\
$\mathrm{~W}$ & $\mathrm{~cm}$ & 1.60 & 4.50 & 2.64 & 2.90 & 0.61 & 50.28 \\
LW & $\mathrm{cm}^{2}$ & 5.78 & 46.35 & 17.53 & 40.57 & 8.82 & 49.41 \\
OLA & $\mathrm{cm}^{2}$ & 3.99 & 35.66 & 13.44 & 31.67 & 6.64 & \\
\hline
\end{tabular}

The nine equations generated from OLA in function of the L, W and LW measurements in the linear models of first degree, quadratic and power can be seen in Table 2. Note that there is a strong association between the relationship of OLA with the allometric measurements of the leaves, explained by the high values of the coefficient of determination $\left(\mathrm{R}^{2}\right)$, presenting values higher than 0.90 . However, the selection of the best equation should not only take into account the high values of $\mathrm{R}^{2}$, since this practice may generate inaccurate estimations of the leaf area (Antunes et al., 2008). Thus, a set of collected data for the validation of the equations must be used, this validation indicates the ability of the models to estimate the leaf area, being an important method to define the precision of the equations (Neter, Kutner, Nachtshein, \& Wasserman, 1996). In this way, the validation parameters aim to analyze the relationship between the foliar dimensions and to test the precision of the data obtained in the estimation of the leaf area.

Table 2. Equation with linear adjustment of first degree, quadratic and power and its respective coefficient of determination $\left(\mathrm{R}^{2}\right)$ using the observed leaf area (OLA) as dependent variable, in function of length (L), width (W), product of length with width (LW) of leaflets of Schinus terebinthifolius Raddi

\begin{tabular}{lll}
\hline Model & Equation & $\mathrm{R}^{2}$ \\
\hline Linear & ELA $=-8.10036+3.41712(\mathrm{~L})$ & 0.9291 \\
Linear & ELA $=-12.3727+9.7143(\mathrm{~W})$ & 0.8948 \\
Linear & ELA $=0.563995+0.741001(\mathrm{LW})$ & 0.9888 \\
Quadratic & ELA $=1.06832+0.34907(\mathrm{~L})+0.24238(\mathrm{~L})^{2}$ & 0.9441 \\
Quadratic & ELA $=-2.6646+2.2124(\mathrm{~W})+1.3953(\mathrm{~W})^{2}$ & 0.9069 \\
Quadratic & ELA $=0.0109455+0.8065607(\mathrm{LW})-0.0016474(\mathrm{LW})^{2}$ & 0.9894 \\
Power & $\mathrm{ELA}=0.5941(\mathrm{~L})^{1.6766}$ & 0.9437 \\
Power & $\mathrm{ELA}=1.9451(\mathrm{~W})^{1.9436}$ & 0.9049 \\
Power & $\mathrm{ELA}=0.8878(\mathrm{LW})^{0.9532}$ & 0.9892 \\
\hline
\end{tabular}

When validation was done from the 96 leaflet sample of Schinus terebinthifolius Raddi, it was verified that among the models tested only the quadratic and power equations based on W, presented a linear coefficient $\left(\widehat{\beta}_{n}\right)$ statistically equal to zero and angular coefficient $\left(\widehat{\beta}_{1}\right)$ not unlike one (Table 3$)$. According to Carvalho, Toebe, Tartaglio, Bandeira and Tambara (2017), this criterion is fundamental in choosing the best adjustments because this indicates that if the observed leaf area is zero, the estimated leaf area will also have values close to zero, so as the leaf area is increased, the estimate of the leaf area for the proposed models will increase gradually and close to the unit. 
Table 3. Linear coefficient $\left(\widehat{\beta}_{0}\right)$, angular coefficient $\left(\widehat{\beta}_{1}\right)$ and determination coefficient $\left(\mathrm{R}^{2}\right)$, obtained from equations with first-line linear adjustment between observed leaf area (OLA) and estimated leaf area (ELA) by length (L), width (W) and length product with the width (LW) of leaflets of Schinus terebinthifolius Raddi used for validation

\begin{tabular}{lllll}
\hline Modelo & Variável & $\widehat{\beta}_{0}$ & $\widehat{\beta}_{1}$ & $\mathrm{R}^{2}$ \\
\hline Linear & $\mathrm{L}$ & $-1.39677^{*}$ & $1.10867^{*}$ & 0.9222 \\
Linear & $\mathrm{W}$ & $-0.98624^{*}$ & $1.08628^{*}$ & 0.9479 \\
Linear & $\mathrm{LW}$ & $-0.2936^{*}$ & $1.0129^{\text {ns }}$ & 0.9936 \\
Quadratic & $\mathrm{L}$ & $-1.04848^{*}$ & $1.07146^{*}$ & 0.9541 \\
Quadratic & $\mathrm{W}$ & $-0.35562^{\text {ns }}$ & $1.02751^{\text {ns }}$ & 0.9574 \\
Quadratic & $\mathrm{LW}$ & $-0.411248^{*}$ & $1.024372^{*}$ & 0.9929 \\
Power & $\mathrm{L}$ & $-1.01810^{*}$ & $1.07294^{*}$ & 0.9490 \\
Power & $\mathrm{W}$ & $-0.35521^{\text {ns }}$ & $1.02438^{\text {ns }}$ & 0.9564 \\
Power & $\mathrm{LW}$ & $-0.403401^{*}$ & $1.021958^{*}$ & 0.9934 \\
\hline
\end{tabular}

When we analyzed the MAE, RMSE and d evaluation criteria, we found that the LW based linear model presented more satisfactory results, however, this model did not meet the validation criterion with $\beta_{0}$ and $\beta_{1}$ statistically different from zero and one, respectively. Among the models that met the coefficient test, the quadratic model with $\mathrm{W}$ as the independent variable presented values of E, MAE and RMSE closer to zero, in addition, this model presented the highest value between the comparison of means of ELA and OLA by the $t$ test $(\mathrm{p}<0.05)$, confirming a greater similarity between these two variables.

Table 4. Observed leaf area (OLA) and estimated leaf area (ELA) of linear equations of first degree, quadratic and potential for the independent variables length (L), width (W) and product of length and width (LW), besides the value of $p$, mean error (E), mean absolute error (MAE), root mean square error (RMSE) and Willmott $d$ index of leaflets of Schinus terebinthifolius Raddi used for validation

\begin{tabular}{|c|c|c|c|c|c|c|c|c|}
\hline Model & Variable & OLA & ELA & $p$ value & $\mathrm{E}$ & MAE & RMSE & $\mathrm{d}$ \\
\hline Linear & $\mathrm{L}$ & & 13.3812 & 0.9490 & -0.0580 & 1.4305 & 1.9555 & 0.9746 \\
\hline Linear & W & & 13.2791 & 0.8610 & -0.1612 & 1.2275 & 1.6086 & 0.9834 \\
\hline Linear & LW & & 13.5571 & 0.9010 & 0.1197 & 0.4191 & 0.5517 & 0.9982 \\
\hline Quadratic & $\mathrm{L}$ & & 13.5209 & 0.9286 & 0.0831 & 1.1884 & 1.4893 & 0.9861 \\
\hline Quadratic & W & 13.4386 & 13.4249 & 0.9884 & -0.0138 & 1.0836 & 1.3815 & 0.9885 \\
\hline Quadratic & LW & & 13.5203 & 0.9312 & 0.0825 & 0.4345 & 0.5874 & 0.9979 \\
\hline Power & $\mathrm{L}$ & & 13.4739 & 0.9693 & 0.0356 & 1.2231 & 1.5634 & 0.9845 \\
\hline Power & W & & 13.4656 & 0.9771 & 0.0272 & 1.1057 & 1.3946 & 0.9883 \\
\hline Power & LW & & 13.5446 & 0.9110 & 0.1071 & 0.4243 & 0.5664 & 0.9981 \\
\hline
\end{tabular}

Thus, in this study for the estimation of leaf area of leaflets of Schinus terebinthifolius Raddi we recommend the quadratic model equation ELA $=-2.6646+2.2124(\mathrm{~W})+1.3953(\mathrm{~W})^{2}$, using only width as measurement. The use of only one dimension to determine the leaf area of a crop is easier to perform when comparing the equations obtained from two dimensions because it requires less effort in obtaining the measurements. According to Santos et al. (2016), the biggest advantage of this type of model is the $50 \%$ reduction in the number of measurements when compared to two dimensional models.

This type of equation based on a measure ( $\mathrm{L}$ or $\mathrm{W}$ ) has already been reported as more accurate in several studies for the determination of mathematical equations as described by Rouphael et al. (2007), Toebe et al. (2010), Buttaro et al. (2015) e Schmildt et al. (2016). According to Buttaro et al. (2015) these models are used with high precision, mainly due to its simplicity and convenience. Moreover, after the models have been established, these equations can be used in a continuous way throughout the cycle, without the need of destruction of the plant and without the obligation of specific equipment to determine the leaf area, a practice that can be done with a simple ruler.

\section{Conclusion}

The leaf area of Schinus terebinthifolius Raddi can be estimated quickly and accurately by maximum leaflet width, non-destructively by the quadratic model equation $\mathrm{ELA}=-2.6646+2.2124(\mathrm{~W})+1.3953(\mathrm{~W})^{2}$. 


\section{Acknowledgements}

CNPq, CAPES and FAPES for financial support.

\section{References}

Alvares, C. A., Stape, J. L, Sentelhas, P. C., Gonçalves, J. L. M., \& Sparovek, G. (2014). Köppen's climate classification map for Brazil. Meteorologische Zeitschrift, 22(6), 711-728. https://doi.org/10.1127/ 0941-2948/2013/0507

Alves, M. L., Souza, M. C., Loff, G. H. G., Marques, R. A., Teodoro, P. E., Correa, C. C. G., ... Torres, F. E. (2016). Linear Model in the Estimate the Sunn (Crotalaria juncea L.) Leaf Area. Journal of Agronomy, 15(2), 83-87. https://doi.org/10.3923/ja.2016.83.87

Antunes, W. C., Pompelli, M. F., Carretero, D. M., \& Damatta, F. M. (2008). Allometric models for non-destructive leaf area estimation in coffee (Coffea arabica and Coffea canephora). Annals of Applied Biology, 153(1), 33-40. https://doi.org/10.1111/j.1744-7348.2008.00235.x

Bianco S., Bianco M. S., \& Carvalho L. B. (2008). Estimate of Ageratum conyzoides leaf area using leaf blade linear measurements. Acta Scientiarum Agronomy, 30(4), 519-523. https://doi.org/10.4025/actasciagron. v30i4.5311

Blanco, F. F., \& Folegatti, M. V. (2005). Estimation of leaf area for greenhouse cucumber by linear measurements under salinity and grafting. Scientia Agricola, 62(4), 305-309. https://doi.org/10.1590/ S0103-90162005000400001

Braga, F. G., Bouzada, M. L., Fabri, R. L., Matos, M. O., Moreira, F. O., Scio, E., \& Coimbra, E. S. (2007). Antileishmanial and antifungal activity of plants used in traditional medicine in Brazil. Journal of Ethnopharmacology, 111(2), 396-402. https://doi.org/10.1016/j.jep.2006.12.006

Buttaro, D., Rouphael, Y., Rivera, C. M., Colla, G., \& Gonnella, M. (2015). Simple and accurate allometric model for leaf area estimation in Vitis vinifera L. genotypes. Photosynthetica, 53(3), 342-348. https://doi.org/10.1007/s11099-015-0117-2

Carvalho, J. O., Toebe, M., Tartaglio, F. L., Bandeira, C. T., \& Tambara, A. L. (2017). Leaf area estimation from linear measurements in different ages of Crotalaria juncea plants. Anais da Academia Brasileira de Ciencias, 89(3), 1851-1868. https://doi.org/10.1590/0001-3765201720170077

Ceruks, M., Romoff, P., Fávero, O. A., \& Lago, J. H. G. (2007). Polar phenolic constituents from Schinus terebinthifolius Raddi (Anacardiaceae). Química Nova, 30(3), 597-599. https://doi.org/10.1590/S0100-4042 2007000300018

Degáspari, C. H., Waszczynskyj, N., \& Prado, M. R. M. (2005). Antimicrobial activity of Schinus terebenthifolius Raddi. Ciência e agrotecnologia, 29(3), 617-622. https://doi.org/10.1590/S1413-70542005 000300016

Ferreira, E. B., Cavalcanti, P. P., \& Nogueira, D. A. (2018). Package 'ExpDes.pt'.

Lorenzi, H., \& Matos, F. J. A. (2008). Plantas medicinais no Brasil (2nd ed., p. 544). Instituto Plantarum, Nova Odessa.

Neter J., Kutner M. H., Nachtshein C. J., \& Wasserman W. (1996). Applied linear regression models (3rd ed.). Irwin, Homewood.

Oliveira Junior, L. F. G., Santos, R. B., Reis, F. O., Matsumoto, S. T., Bispo, W. M. S., Machado, L. P., \& Oliveira, L. F. M. (2013). Fungitoxic effect of essential oil from aroeira (Schinus terebinthifolius Raddi) on Colletotrichum gloeosporioides. Revista brasileira de plantas medicinais, 15(1), 150-157. https://doi.org/ 10.1590/S1516-05722013000100021

Oliveira, V. S., Santos, K. T. H., Ambrósio, T. J., Santos, J. S. H., Santana, W. R., Malikouski, R. G., ... Schmildt, E. R. (2019). Mathematical Modeling for Leaf Area Estimation from Papaya Seedlings 'Golden THB'. Journal of Agricultural Science, 11(4), 496-505. https://doi.org/10.5539/jas.v11n5p496

Paiva, A. M. S., \& Aloufa, M. A. I. (2009). In vitro establishment of Brazilian pepper (Schinus terebinthifolius Raddi) at different concentrations of 6-benzylaminopurine. Revista Brasileira de Plantas Medicinais, 11(3), 300-304. https://doi.org/10.1590/S1516-05722009000300011

Peksen, E. (2007). Non-destructive leaf area estimation model for faba bean (Vicia faba L.). Scientia Horticulturae, 113(4), 322-328. https://doi.org/10.1016/j.scienta.2007.04.003 
Pompelli, M. F., Antunes, W. C., Ferreira, D. T. R. G., Cavalcante, P. G. S., Wanderley Filho, H. C. L., \& Endres, L. (2012). Allometric models for non-destructive leaf area estimation of Jatropha curcas. Biomass and Bioenergy, 36, 77-85. https://doi.org/10.1016/j.biombioe.2011.10.010

$\mathrm{R}$ Core Team. (2018). R: A language and environment for statistical computing. Vienna: R Foundation for Statistical Computing, Vienna, Austria.

Ribeiro, A. M. S., Mundim, D. A., Mendonça, D. C., Santos, K. T. H., Santos, J. S. H., Oliveira, V. S., ... Schmildt, E. R. (2019). Leaf Area Estimation of Garden Boldo from Linear Dimensions. Journal of Agricultural Science, 11(4), 461-469. https://doi.org/10.5539/jas.v10n12p272

Rouphael, Y., Colla, G., Fanasca, S., \& Karam, F. (2007). Leaf area estimation of sunflower leaves from simple linear measurements. Photosynthetica, 45(2), 306-308. https://doi.org/10.1007/s11099-007-0051-z

Santana, J. S., Sartorelli, P., Lago, J. H. G., \& Matsuo, A. L. (2012). Isolation and evaluation of cytotoxic potential of phenolic derivatives from Schinus terebinthifolius Raddi (Anacardiaceae). Química Nova, 35(11), 2245-2248. http://doi.org/10.1590/S0100-40422012001100029

Santos, J. C. C., Costa, R. N., Silva, D. M. R., Souza, A. A., Moura, F. B. P., Silva Junior, J. M., \& Silva, J. V. (2016). Use of allometric models to estimate leaf area in Hymenaea courbaril L. Theoretical and Experimental Plant Physiology, 28(4), 357-369. https://doi.org/10.1007/s40626-016-0072-8

Schindelin, J., Rueden, C. T., Hiner, M. C., \& Eliceiri, K. W. (2015). The ImageJ Ecosystem: An Open Platform for Biomedical Image Analysis. Molecular Reproduction and Development, 82(7-8), 518-529. https://doi.org/10.1002/mrd.22489

Schmildt, E. R., Oliari, L. S., Schmildt, O., Alexandre, R. S., \& Pires, F. R. (2016). Determination of leaf area in Passiflora mucronata from linear dimensions of the leaf blade. Revista Agro@mbiente On-line, 10(4), 351-354. https://doi.org/10.18227/1982-8470ragro.v10i4.3720

Silva, M. A. V., Nogueira, R. J. M. C., Oliveira, A. F. M., \& Santos, V. F. (2008). Stomatal responses and dry matter yield in young aroeira plants submitted to different water levels. Revista Árvore, 32(2), 335-344. https://doi.org/10.1590/S0100-67622008000200016

Toebe, M., Brum, B., Lopes, S. J, Cargnelutti Filho, A., \& Silveira, T. R. (2010). Estimate leaf area of Crambe abyssinica for leaf discs and digital photos. Ciência Rural, 40(2), 445-448. https://doi.org/10.1590/ S0103-84782010000200036

Toebe, M., Cargnelutti Filho, A., Loose, L. H., Heldwein, A. B., \& Zanon, A. J. (2012). Leaf area of snap bean (Phaseolus vulgaris L.) according to leaf dimensions. Semina, 33(1), 2491-2500. https://doi.org/10.5433/ 1679-0359.2012v33Supl1p2491

Vitória, E. L., Freitas, I. L. J., Locatelli, T., Lacerda, E. G., Valle, J. M., Pereira, R. C., ... Fernandes, A. A. (2018). Mathematical Models for Leaf Area Estimates of Guava. Journal of Agricultural Science, 10(12), 272-278. https://doi.org/10.5539/jas.v10n12p272

Willmott, C. J. (1981). On the validation of models. Physical Geography, 2(2), 184-194. https://doi.org/10.1080/ 02723646.1981 .10642213

\section{Copyrights}

Copyright for this article is retained by the author(s), with first publication rights granted to the journal.

This is an open-access article distributed under the terms and conditions of the Creative Commons Attribution license (http://creativecommons.org/licenses/by/4.0/). 